\title{
A Darwinian Study of Ammu's Violent Behaviour in the 'The God of Small Things'
}

Muhammad Nawaz

\author{
Assistant Professor, English Department, University of Lahore, Chenab Campus, Pakistan \\ PhD scholar, Imperial University, Lahore, Pakistan
}

\begin{abstract}
This research intends to study the acts of violence in Arundhati Roy's debut novel The God of Small Things with special reference to the female characters. As a social and political activist, Roy has her own perception of violence that is reflected through her female characters especially through her chief protagonist Ammu, a divorced woman, who violates the social norms by having a secret love affair with an untouchable laborer. Thus all the four women in the novel, in one way or the other, evolve, adapt, resist and challenge the hegemonic powers and simultaneously modify the stereotypes about gender and violence. And by doing so, they confirm to the Darwinian approach that violence is innate in human nature, constrained by biology and concurrently embedded in culture.
\end{abstract}

Keywords- violence, The God of Small Things, Protagonist, Darwinian, innate, Stereotypes, Ammu.

\section{INTRODUCTION}

Today the world we live in is replete with incidents of violence, aggression, terrorism and mass killing. Moreover, the tales of conflicts, clashes and violence have a sensational appeal for the readers when penned down by an adept hand. That is why violence has been a prominent theme in the literature of all times. Homer's great epic poem Iliad and its sequel Odyssey, which are the oldest works of literature, contain the tales of violence, war and aggression.

Moreover, the issue of violence is found, directly or indirectly, in the books that we have been reading since childhood. It is found in the sufferings of Cindrella at the hands of her cruel stepmother and stepsisters or in the form of beatings of the Black Beauty at the hands of her cruel master. Hence, due to its sensational appeal, violence found its way in fairy tales, science fictions, and horror stories and in almost all the genres of adult literature. Even the partition of sub-continent was followed by violence and massacre on a large scale.

Not many studies are conducted to explore and investigate the acts of violence originated by women and to explore the key factors; psychological, cultural or biological, which turn the soft and fair sex into a violent and aggressivecreature. This research will explore the fictional work of Roy The God of Small Things to document and register the acts of violence initiated by the female characters

\subsection{Research Objectives:}

The core objectives of this study are to analyze, investigate and study

a. The factors, both environmental and natural, that cause women to adapt and commit the acts of violence in the selected text.

b. The deconstruction of stereotypes about violence and gender through the selected text.

c. The writer's conception and perception of violence and its depiction through her female characters.

\subsection{Research Questions:}

This research will focus on the following key questions:

a. How do major character in Roy's selected work adapt herself to her immediate environment for survival?

b. How far is Roy successful in deconstructing popular stereotypes with respect to violence and gender through the selected text?

c. To what extent is the writer's conception and perception of violence reflected through her female characters?

The publication of the novel The God of Small Things brought great name and fame to its novelist. Today Roy is a renowned Indian novelist, essayist and socio-political activist. Her broken family background and troubled youthful days have their imprints on the pages of her book. The novel contains many autobiographical elements that give us the glimpses of her early life largely. Her father was a Bengali Hindu from Calcutta and her mother, Mary Roy, was a non-traditional Christian social activist. She was an educated and strong-willed woman who rebelled against caste- ridden society by marrying a man out of her caste. After marriage, she refused to succumb to 
the whims and wishes of her husband. When he divorced her, she returned to her ancestral village Ayemenem and assisted her mother in her pickles factory. During those days, Syrian Christian women were not granted share in their father's property. Mary Roy challenged this act in the court and was able to win equal rights for Syrian Christian women in the father's property. Mentioning the effects of their iconoclast mother, Roy's twin-brother Lalit Roy states in an interview, "My mother is a powerful personality and she brought us up to be very independent" (Roy 14). The seven years old Roy worked in her grandmother's pickles factory and helped in packing and labeling the cans. Referring to the troubled family background and its effects on the young Roy, the critic Amar Nath Prasad notes:

Roy was thus the product of a broken home. She had to face several cares and anxieties, fret and fever during her childhood. The Ayemenem house was dominated by the traditional patriarchal clutches. The men in and around the house were conservative in their outlook. This phenomenon can be beautifully seen in the novel where Ammu who represents her mother Mary Roy, has to undergo so many ups and downs. (Nath 1)

The principal narrator of the novel is Rahel. It is through her narration that we come across most of the incidents of their childhood. Actually, through her, Roy gives an insight into her own childhood memories, mostly painful and bitter, and their effects on her later life. Referring to the autobiographical aspects of her novel, Roy herself admits in an interview, "I was an unprotected child in some way. Two things happen. You grow up quickly. And when you become an adult there is a part of you that remains a child, so the communication between you and your childhood remains open" (Roy 14).

She also made media headlines all over the world when her debut novel The God of Small Things won the prestigious Booker Prize in 1997. Since then she has devoted herself to activism and non-fictional writings. She was a proactive participant in the campaign against the notorious Narmada Dam Project of Indian government that put the lives of thousands of poor Indians at stake. For this, she was put behind the bars for a day on charges of contempt of court. She also vehemently criticized thegrowing nuclear programs in India, Pakistan and abroad. She spoke boldly against the American attack on Afghanistan and Iraq. Her support of Kashmiri freedom fighters has made her a controversial figure even in her own country. These days she is a leading figure fighting for the cause of Dalit community in India.

Like her mother, Roy is an iconoclast and rebel who refuses to bow before authority and challenges the precolonial social, cultural and patriarchal norms in her own way. In her novel, she presents the deplorable picture of India that claims to be a champion of democracy and equality but where women are still treated like slaves and inferior creatures. Although the constitution of India grants equal rights to women and especial attention is paid to their rights in various national plans, yet the ground reality is very appalling and heart rendering. Rao in his article about the novel rightly observes:

Roy's book is the only one I can think of among Indian novels in English which can be comprehensively described as a protest novel. It is all about atrocities against minorities, Small Things; children and youth, women and untouchables. (qtd. in Prasad 124).

Summing up we may say that violence is a common thing in the modern world. There is nonetheless a misconception about violence prevalent in almost all the societies that it is only a masculine phenomenon and that the female members of society are not capable of initiating and perpetrating the acts of violence and transgression. In the male dominating social and cultural set ups women have been consideredtimid, passive and weak creatures. This research, however, intends to deconstruct this age- old myth about violence by highlighting the acts of violence perpetrated by the female members of society. The women presented in the novel are not illiterate and ignorant. Rather they are well aware of social conventions, traditions, taboos and politics of the contemporary Indian society. They are the human beings of flesh and blood who commit and initiate the unthinkable acts of violence and transgression without caring for their own lives or of those around them.

\section{REVIEW OF LITERATURE}

Many scholars and researchers have discussed the is sue of violence in detail and a considerable amount of research work is available on the subject. However, most of the research has been conducted to trace the male violence patterns and only a little amount of work is available on the violence initiated by female members of society.

After discussing the key theories and scholarly views on violence and aggression, let us have a look at the popular discourses that are solely about the violent nature of women. These discourses explore the construction of image of violent women and pinpoint the internal and external factors such as self-defense, survival, jealousy, and desire to dominate, to command and to take revenge that may compel "the angel of the house" to behave violently. Being a human being, women have within them 
the energy to resist and behave aggressively whenever they feel their survival is at stake. They can be prompted to retaliate because of some disgrace, jealousy, domestic violence and abuse.

As stated earlier, violence is considered solely masculine and a woman is not expected to perpetrate the acts of violence and aggression. It is considered something shameful and disgraceful in a woman. Such a woman is often labelled as mad, crazy and even abnormal. She is expected to be submissive, selfless and passive. The $19^{\text {th }}$ century literature also popularized the image of woman as a soft, gentle and inferior creature. With the turn of century, education, women rights bills and radical feminists began to empower these hitherto weak creatures and the furious female characters such as Charlotte Bronte's Bertha Rochester, Zora Neale Hurtson's Janie, Susan Glaspell's Minnie Wright etc. began to appear on the horizon of fiction. The image of woman as a vampire and clothed-hyena shocked the male-chauvinistic society and was termed as "abnormal". These "mad women" were isolated from the main stream and often "locked in the attic". They considered a disgrace for the family and therefore kept in the four walls. In this regard, Ussher implores:

A diagnosis of madness denotes an absence of reason, this implies that women who commit crimes, who are violent, are not in control of their senses. Is this because criminality, violence or aggression cannot be reconciled with our conceptualization of femininity, and thus the woman must be mad (qtd in Africa 91).

Whereas men are often applauded for showing violent behavior, these violent women are severely rebuked and often put behind the bars so that they may not spoil the "whole flock". Hence, a woman exhibiting violent tendencies is mostly considered a bitch, mentally upset, power-crazy or possessed by demonic powers. In short, women are not expected to be perpetrators of violence, and if they do, they are dealt with severity and harshness. Consequently, the discourse of mad woman continues to run through in the understanding of female instigators and perpetrators.

Another popular discourse about violent and aggressive women is that the "in appropriate behavior" displayed by women is caused by their battering and abuse by their intimate partners. Researchers such as Dasgupta and Straus note that violent women had had exposure to violence and aggression during childhood. In most of the cases of domestic violence, with women as perpetrators, it has been noted that most of the time these abused women retaliated and hit back their partner in self-defense or to protect their children. Their retaliatory actions are, in fact, an attempt on their part to assert themselves and vent out their depression or frustration. Being a Homo sapiens, they too have the drive to protect themselves and their identity. In order to support his view about conversion of woman from "battered" to "batterer", Dasgupta uses ecological nested model proposed by Uri Bronfenbrenner. This model enlists some key factors that mainly influence and explain variations in individual behavior. It takes into account the individual, societal, cultural and historical elements that are responsible for unusual behavior depicted by female offenders.

The discourse of sexually deviant woman also probes into the violent behavior of women. These deviant women do not conform to the institutional and cultural norms and values. They are labelled as Veshyas (prostitutes) for showing deviant behavior and indulging in sexual adventures. The purpose of this labeling is in fact an endeavor by the society to check and control them with might and mane. The image of a good and ideal woman projected in $19^{\text {th }}$ century literature urges them to be chaste, modest and timid. Even today, they are expected to perform their motherly duties as designed by patriarchal set up. In addition, if they do not confirm to the age-old gender roles, they are categorized as unwomanly:

A recurrent feature of feminine respectability is sexual propriety . . . Historically, women have been judged more harshly than men if they do not meet expectations of appropriate sexual behavior in terms of chasteness and monogamy, and these norms have played a more important role in the regulation of femininity than masculinity. (qtd. in Laws 347)

All these discourses about the violent behavior of women give us a deep insight into the subject under study. However, these discourses study the causes and influences of violence in a different way, the point they unanimously seem to agree is that violence is incongruous with femininity. It is something purely masculine and has nothing to do with the softer sex. That is why women depicting violent and deviant behavior are labelled as abnormal and mad.

On the other hand, feminist theories trace the causes of violent behavior of women in their attempt to resist and challenge patriarchy, phallocentric social set up and precolonial power structures that dehumanize and devalue women and all their achievements. They argue that all through human history women have been assigned a secondary status. Even Aristotle was of the view that they are imperfect creatures. In Greek mythology, we find that 
almost all the evil passions such as envy, jealousy, hatred and anger were associated with women. The dominant religious belief among Christians and many other religions is that as the woman is created out of Adam's rib, she is incapable of rational behavior. She is mostly blamed for the banishment of Adam from paradise. This in turn generated stereotypes about women that they are unwise and inferior to men. They were considered mere wombs that had bearing children as their only purpose of existence.

During wars women were frequently raped, killed, held captives and made slaves. The feminists used all this exploitation of women for their cause and incited women to violate and rebel against all these so called power structures and break the traditional stereotypes. Bourgeois feminism of Virginia Woolf made the women realize that it is their financial dependence on men which is preventing them from writing. She assured them that they would be as productive as men only if they gain financial stability. The socialist feminist Simone de Bouvoir exposed the hollowness of traditional and pre-colonial stereotypes of women in male narratives. Bouvoir advocated that social equality between the sexes is necessary in order to liberate and empower women. The French feminism also provoked the women writers to discard the masculine mode of expression and develop their own language and mode.

Hence, all the feminist movements, in one way or the other, encourage women to realize their potential and rebel against traditional, social, cultural and patriarchal barriers. As a result, of this awakening, more and more women started taking part in masculine acts such as doing jobs, starting their own business, joining armed forces etc. Their violent behavior may also be a result of their newly found freedom.

\section{MATERIALS AND METHODS:}

\subsection{Object of the Study:}

The object of this research is a novel by a renowned Indian writer and activist Arundhati Roy entitled The God of Small Things.

\subsection{Research Approach:}

The core objective of this research is to investigate and explore the acts of female-initiated violence in the selected text. For this purpose, qualitative research approach is adopted to accomplish this task as it intends to find out reasons behind human actions and behavioral patterns. It also takes a holistic approach in order to seek aclear understanding of the area of study.

\subsection{Research Methods:}

Research method is the technique or skill that is employed to carry out research. For the purpose of this study descriptive, exploratory and analytical methods are employed to find answers to the research questions. . Moreover, in order to make this study quite objective and a bit scientific, the evolutionary behavior patterns of the selected characters are analysed and tested in the light of behavioral pattern explanations framed by the famous Dutch biologist Nikolaas Tinbergen who distinguished among four different types of explanations when dealing with behavior patterns. These are Proximate explanations that refer to the proximate causes of behavior such as nerve impulses, developmental explanations that describes how a behavior comes about over time, natural selection explanations that tells how natural selection and evolutionary processes interact to shape behavior and finally phylogenetic explanations that looks at the evolutionary history of species. These explanations can be expressed as four questions about the behavioral patterns of an organism: what is it for? How did it develop? How did it evolve? And how does it work? By using mainly the first three explanations the researcher has attempted to prove that the odd behavioral patterns of the selected characters have evolved due to environmental and natural factors and in order to do this the researcher has aptly selected a Darwinian framework to conduct this research study.

\subsection{Data Sources:}

The primary source of data in this research is the text of the novel The God of Small Things by Roy. The secondary sources of data for this study are the relevant critical commentaries, published scholarly articles, research papers, approved theses, critical books, author's own interviews, essays, and analysis of female characters of the novel by the renowned scholars. The data, collected through primary and secondary sources is then analyzed and evaluated in the perspective of Darwinism that provides the theoretical framework for this research.

\subsection{Theoretical Framework:}

The theoretical framework of this study is Darwinism or Darwinian Theory. Charles Darwin was a British naturalist and scientist who is well known for his famous theory of evolution by natural selection. A few decades ago, the ideas and theories of Charles Darwin were considered only for the field of natural sciences. As Science and Humanities were poles apart from each other, no one could think of applying Darwin's ideas to interpret the behavioral patterns of characters in literature. Though Darwin's ideas of a cruel godless cosmos began to influence the writers like Hardy, Bernard Shaw, Tennyson 
and Conrad, no work of scholarship emerged that had application of Darwin's ideas. It was during the last decade of 20th century that Darwin's theories began to enter into various disciplines such as Sociology, Anthropology and Psychology.

The scholars of these disciplines began to explain the various phenomena in terms of evolution by natural selection. They began to apply the ideas of evolutionary biology to human behavior. This gave birth to a new field of studies that is called Darwinism or Darwinian Studies. According to a scholar of Darwinian studies, "There is no work of literature written anywhere in the world, at any time, by any author, that is outside the scope of Darwinian analysis" (Carroll 79).

Darwinism is a way of studying literature from the perspective of evolution by means of natural selection, including gene-culture co-evolution. It is a bio-cultural concept that intends to "integrate literary concepts with a modern evolutionary understanding of the evolved and adapted characteristics of human nature" (Carroll 79). The main objective of a Darwinist is to have evolutionary understanding of those characteristics of human nature that have evolved and adapted with the passage of time. A Darwinist primarily focuses on identifying innate human traits and then using them to describe the behavior patterns of characters in art and literature. He also focuses on the relation of genetically transmitted dispositions and specific culture configuration.

According to Darwin, evolution is actually a kind of "descent with modification". It means that all the living things do evolve with the passage of time. During this process of evolution species undergo various changes and gradually give birth variable species that are better able to survive in their immediate environment. And this evolution occurs through natural selection. By natural selection Darwin means that the frequency of favorable inherited traits increases whereas the unfavorable and harmful traits begin to decrease and diminish in the successive generations and it is through natural selection that the species become adapted to their changing local conditions.

\subsection{Delimitations of the Research}

This research project is limited to the investigation and exploration of acts of violence originated by the female characters especially major one in Roy's debut novel The God of Small Things only. The focus of the researcher, therefore, is on the female-initiated acts of violence that are studied in the perspective of Darwinism. It has not explored the male violence patterns prevalent in the text. It has not studied the issues related to formations of genes, genetic mutations, DNA, ontogeny, phylogeny and ethology in detail. However, while conducting this research, the problem of shortage of recent, authentic and empirical data on the subject under study has been faced by the researcher.

\subsection{Validity and Reliability of Data}

During the process of collecting data for this research project the most important thing that has been kept in mind are the accuracy, validity, reliability and appropriateness of the data. Every effort has been made by the researcher to ensure that the collected data and the findings based on this data have credibility, transferability, dependability and conformability.

\section{DISCUSSION}

In her Pulitzer Prize winner debut novel titled The God of Small Things Roy presents three generations of women in postcolonial India. Mammachi and Kochamma belong to the first generation of women who undergo the process of evolution and adaptation and thus violate and defy the patriarchal assumptions about women as being oppressed and marginalized. Ammu belongs to the second generation of women who break all the boundaries of caste and class and spreads her wings to escape from the cast ridden social set up. Her daughter Rahel falls in the category of third generation of women who violate the love laws "that lay down who should be loved. And how. And how much" (328). The acts of evolution, adaptation and violence perpetrated by these women can be explained and justified from the perspective of Darwinian Theory. Darwin studied animals in detail for about thirty years to explore their behavior patterns. Similarly, a Darwinist studies the characters of a text in order to discover innate human traits and behavior patterns with special attention to the universal patterns of behavior that are instinctual, genetically transmitted and inherited from parents to offspring. The female characters in this novel display violence and aggression as they are biologically programmed to do so. These women, viewed from Darwinian point of view, compete and transgress for the selection of suitable mates to ensure the survival of their offsprings.

The violent reaction of Mammachi and Baby Kochamma on Ammu-Velutha sexual liaison can be justified from Darwinian point of view. They are much concerned about their genetic material and the possibility of its getting mixed with an Untouchable species provokes their anger and rage. Ammu's choice of Velutha, from Darwinian point of view, is indeed an attempt on her part to select a powerful mate that will help secure her and her offsprings. 
Rahel's violation of love laws is an example of mating behavior that, according to evolutionary psychologists, motivates individuals to copulate with their blood relations. Moreover, the unconventional and violent behavior patterns of the selected women are quite in keeping with Tinbergen's explanations about behavior patterns. His explanations of can be expressed as four questions about the behavioral patterns of an organism: What is it for? How did it develop? How did it evolve? And how does it work? Although the primary focus of Tinbergen was on behavior, these questions apply broadly to any characteristic in living systems. In this chapter the researcher has explored and analysed the odd behavioral patterns exhibited by the major female characters of the selected text as well as natural and environmental factors that cause these patterns in the light of Darwin's theory of evolution through natural selection according to which all the species, irrespective of gender and sex, have an instinct to put a violent struggle in order to survive and continue their race in the ever changing environment.

\subsection{Tracing Environmental Factors behind Ammu's Violent Behaviour, her Adaptation and Struggle for Survival}

Ammu is the tragic heroine of the novel. She is the central character around whom the main plot of the novel revolves. From childhood till her early death, she has to pass through fire and water. Although beaten and abused as a daughter, marginalized as a sister, mistreated as a wife, disapproved as a mother and silenced as a lover, she is a modern day educated woman and has the spark to resist and violate the traditional norms and values with conviction and determination and her behavioral patterns are quite in keeping with Darwinian theory of evolution through natural selection.As a daughter, Ammu and her mother had to suffer at the hands of her abusive father. Her frequent exposure to domestic violence during childhood had madeher aware of the brutalities of patriarchy and harsh realities of life. Her father was "charming and urbane" (180) with outsiders and "worked hard on his public profile as a sophisticated, generous, moral man" (180). Only Ammu and her mother knew that he was a "male chauvinist pig" (83) and when "alone with his wife and children he turned into a monstrous, suspicious bully with a streak of vicious cunning. They were beaten, humiliated and then made to suffer the envy of friends and relations for having such a wonderful husband and father" (Roy180). As a result, Ammu was no longer afraid of violence and transgression. Rather she seemed to have evolved and developed violent tendencies and even felt a kind of pleasure in them as Roy notes:
As she grew older, Ammu learned to live with this cold calculating cruelty. She developed a lofty sense of injustice and the mulish, reckless streak that develops in Someone Small who has been bullied all their lives by Someone Big. She did exactly nothing to avoid quarrels and confrontations. In fact, it could be argued that she sought them out, perhaps even enjoyed them. (181- 82) Consequently, there developed the "reckless rage of a suicide bomber" in her when she grew up (Roy 321). She seems to have inherited and developed it from her sadist father over time. She was deprived of college education because her conservative father thought that "a college education was an unnecessary expense for a girl" (Roy 38). When her father retired from his job, the family moved from Delhi to their ancestral home in the small town of Ayemenem where "there was very little for a young girl to do other than to wait for marriage proposals while she helped her mother with the housework" (Roy 38). Ammu soon was fed up of this deplorable situation and when she got permission to spend a few days of summer with a distant aunt in Calcutta, she promptly availed herself of this chance and found a husband for herself over there. After marriage, she moved with him to Assam where he worked as an assistant manager in a tea estate. Soon Ammu came to know that her husband was an alcoholic and work shirker. When he tried to prostitute her to his English boss in exchange for his job, Ammu divorced him and returned to her family home along with her twins; Estha and Rahel. As she was not welcomed home, she tried to earn her keep by working with her mother in the family's pickle factory. It was here in Ayemenem that she fell in love with untouchable laborer that, when discovered, caused her expulsion from home and led to her early death. However, what makes Ammuato towering female character is that despite all the heavy odds, she refuses to bow before authority, patriarchy and traditional social values.

On the contrary, she violates these so-called norms set by conservative society and thus proves herself a strong and rebellious character. Acts of violence and transgression perpetrated by such a weak and oppressed woman as Ammu may appear surprising and shocking. Hence, viewed from the perspective of Darwinian Theory one must not forget the fact that she is a human being too, a Homo sapiens, and like her male counterparts, has the instinct to resist and challenge the power structures in order to ensure her survival, self- defense and continuity of race. Her impulsive decision to marry is quite in keeping with Tinbergen's immediate causation that refers to proximate causes of behavior. Let us explore some acts 
of violence initiated by Ammu in various chapters of the novel and see how they confirm to the idea that violence is an instinct inherited, shared and possessed not only by men but also women as well and how does evolutionary process help her adapt and better suited to her immediate environment.

In the very first chapter of the novel, we find Ammu going to Kottayam police station after the funeral of her niece. She met the station house officer and told him that "there had been a terrible mistake and that she wanted to make a statement" (Roy 7). Sheeven asked to see Velutha, her untouchable lover, who has been beaten and locked up on charges of abduction and sexual harassment as levied against him by Baby Kochamma in her FIR. Generally, women in a conservative society like India are not expected to visit the police station. However, Ammu is bold enough to violate the traditions. Even the members of her family do not expect her to go to police station and demand seeing her lover:

When Baby Kochmma heard about Ammu's visit to the police station, she was terrified. Everything that she, Baby Kochmma had done, had been premised on one assumption. She had gambled on the fact that Ammu, what else she did, however angry she was, would never publically admit to her relationship with Velutha. Because, according to Baby Kockmma, that would amount to destroying herself and her children forever. Nevertheless, Baby Kochmma had not taken into account the unsafe edge in Ammu. The unmixable mix ... the infinite tenderness of motherhood, the reckless rage of a suicide bomber. (Roy 321)

What the people around Ammu fail to understand is that being a human being she has an innate trait to violate and transgress whenever she sensed threat. Hence, the novel can be interpreted from the point of view of Darwinian Theory that focuses mainly on identifying innate human traits and then using them to describe behavior patterns of characters.

The glimpses of Ammu's violent nature can be seen in her disagreement and dissent with the opinion of people around her. Being a divorcee, she is expected to be grateful to the members of her family and bow before them. But "she is not that sort of person". When the exwife of her brother Chacko comes to stay with them for Christmas, Ammu does not care much for formalities as observed by others and goes to the extent of making fun of Margaret's comments about sniffing and kissing without any fear and hesitation. Her bother orders her to apologize to his ex-wife but Ammu simply "walked back to Plymouth, took out her suitcase, slammed the door and walked away to her room, her shoulders shining. Leaving everybody to wonder where she had learnt her effrontery from" (Roy 180). She openly challenges her brother when he tries to lecture her on proper upbringing of children in these words, "Stop posing as the children's great savior! Ammu said. When it comes down to brass tacks, you don't give a damn about them. Or me" (Roy 85).

At another occasion, she violently challenges her mother's opinion about her brother. Like a typical Indian mother, Mammachi was in the habit of exaggerating the achievements of her son. When Mammachi said that her son was "one of the cleverest men in India" (56) and told her favorite story of how "one of the dons at Oxford had said that in his opinion, Chacko was brilliant and made of prime ministerial material" (Roy 56), Ammu laughs at her mother and challenges her opinion boldly asserting that "all Indian mothers are obsessed with their sons and are therefore poor judges of their abilities" (Roy 56). These incidents, however, trivial they may be, help us to understand the violent and defiant side of Ammu's character.

Another act of female-initiated violence committed by Ammu is described in the second chapter of the novel. After her love marriage with a Bengali Hindu, Ammu moved to Assam with her husband where he worked as an assistant manager in a tea estate. There, to Ammu's surprise, her charming husband turned out to be not just a heavy drinker but a full blown alcoholic with all of an alcoholic's deviousness and tragic charm. It was here that Ammu gave birth to her twins and "by the time the twins were two years old, their father's drinking, aggravated by the loneliness of a tea estate life, had driven him into an alcoholic stupor" (Roy 41). He was always drunk and did not want to work for many days. One day his English boss Mr. Hollick called him to his bungalow for a "serious chat", reprimanded him for his excessive drinking and threatened to fire him. However, Mr. Hollick had an eye on Ammu who had become "the toast ofthe Planter's Club" (Roy 40). Thus, he proposed her husband to go away for sometimes to a clinic for the treatment of his alcoholism and leave his beautiful wife and children in his bungalow. He assured him that they would be "looked after" (Roy 42) well in his bungalow. When he came home, he talked to Ammu about the proposition of his manager. At first Ammu was so shocked that she found herself unable to speak. But, when her bullying husband began to beat her, "lunged at her, grabbed her hair, and punched her" (Roy 42), She could not control her anger and to the surprise of her husband, retaliated with full force as Roy describes: 
Ammu took the heaviest book she could find in the book shelf- the Reader's digest world atlas- and hit him with it as hard as she could. On his head and his legs. His back and shoulders. When he regained consciousness, he was puzzled by his bruises. (Roy 42)

Even after being beaten violently by his wife, the wretched husband kept on persuading her to accept this indecent proposal. Ammu was unable to cope with his humiliating attitude so "she divorced her husband and returned, though unwelcomed, to her parents in Ayemenem" (Roy 42). This act of domestic violence initiated by Ammu, though shocking and unusual to some readers, seems quite justified when viewed from the perspective of Darwinism as it helps us to have an evolutionary understanding of those traits of human nature that have been evolved and adapted with the passage of time. Her rejection of an alcoholic husband is quite in common with Darwin's idea that female rejects that male whom she considers misfit and inappropriate for her offs pring.

Ammu's rejection of motherhood and act of giving divorce is quite in keeping with evolutionary theory. Although she is an oppressed, neglected and ignored woman, yet all these sufferings have failed to subdue her instinctual passions or tame her animalistic instinct of violence and transgression. Repeatedly in the story, we find her blaming twins for her troubles. No doubt, like a traditional mother, she loved them heart and soul. But sometime she hated them, "was quick to reprimand" (Roy 43) them and wanted to hurt them:

On days like this, there was something restless and untamed about her. As though she had temporarily set aside the morality of motherhood and divorcehood. Even her walk changed from a safe mother- walk to another wilder sort of walk ... She smoked cigarettes and had midnight swims. (Roy 44)

Even her kids remember her fury when she divorced her husband and fought with himover the issue of upbringing of twins. She pushed her son Estha towards him asking him to look after one kid. He refused to oblige and pushed Estha back. Estha still "remembered being pushed around a room once, from Ammu to Baba to Ammu to Baba like billiard balls" (84).

After the exposure of Ammu's secret sexual liaison with Velutha, she was locked up in her bedroom, like a family lunatic in a medieval house. She considered her kids responsible for this detention. If it were not for them, she would have escaped with her untouchable lover and lived her life to her fill. In a fit of fury she yelled at them in these words;

If it wasn't for you I wouldn't be here! None of this would have happened! I wouldn't be here! I would have been free! I should have dumped you in an orphanage the day you were born! You're the millstones round my neck. (Roy 253)

We do not expect such a rage and anger from a mother against her kids. Nevertheless, Ammu is an exception. She had "an unmixable mix, the infinite tenderness of motherhood, the reckless rage of a suicide bomber" (Roy 321). She is portrayed as a violent and untamed mother who defiantly "shrugged her children off the way a bitch shrugs off her pups when she's had enough of them" (Roy 222).

Another act of violence committed by Ammu is seen in her act of breaking the love laws by having a sexual liais on with an untouchable which ultimately leads to the death and destruction of both. Referring to the love laws in this novel a renowned critic Scott Trudell asserts:

The love laws represent the strict confines on human behavior- thecast systems, social pressures, and political restrictions that horrify people beyond expression when they are broken. The central action of the novel is about breaking them and the tragedy that results from breaking them. (Roy 165)

Actually, after divorcing her husband, Ammu is leading a desperate and lonely life in the big house. She is considered a burden on the family and her twins are not welcomed to the house of their maternal. In her frustration, she develops a physical relation with an untouchable Velutha who works in the pickle factory of her mother. She had known him since childhood. Even when he was a little boy, he was expert at carving wooden toys such as "boats, boxes, small windmills" (Roy 175). When the whole family was busy in "Welcome Home, Our Sophie Mol" celebrations, she noticed Velutha playing in the shade of trees with her daughter. She noticed his "swimmer carpenter's body. Polished with a high-wax body polish" (175). She developed a liking for his athletic body and "ached for him with the whole of her biology" (330). In addition, in order to satisfy her desire she was more than willing to cross the barriers of caste and class and love the man at night her kids used to love during day time. This violent act of breaking the love laws plays a catalytic role in initiating the death and destruction in the novel. Referring to this particular aspect of Ammu's character the critic Scott Trudell aptly comments: "When [Ammu] recognizes that Kerala's social code is in the process of forcing her down Baby Kochmma's path of bitter, joyless confinement to the house until death, she acts in perfectly understandable desperation and attempts to find some brief joy with Velutha" (Roy 165). 
Hence, we may say that Ammu is one of the chief initiators and perpetrators of violence in the story. Although she is a divorced woman, she has the energy and courage to resist and challenge the power structures around her. By doing this, she paves the way for modern day Indian women to resist the authority with courage. It is through the acts of violence perpetrated by Ammu that the writer has tried to give voice to the subaltern women who are now bold enough to protest vehemently against the prevalent power structures. Moreover, her acts of violence are quite justified when viewed from the perspective of Darwinian Theory. First, she rejected her husband because she considered him misfit for her offspring. Secondly, her attraction for Velutha is also justified as according to Darwin's idea that female search for healthy and strong male to ensure the safety of their offspring and receive better genetic material. Thirdly, her violent outbursts are, in fact, her attempts for survival and self- defense. Like animals, she too inherits the instinct to retaliate and behave violently when she found her safety at stake. Moreover, excessive exposure to domestic violence during childhood had made her learn and adopt the violent behavior. Her father was a sadist and aggressive person and Ammu inherited and possessed his genetic material. All these unusual behavior patterns such as hasty marriage, beating of her bullying husband and divorcing him, rejection of motherhood, her moody and indifferent attitude, developing an illicit relationship with an untouchable etc. are quite in harmony with Tinbergen's explanations of behavioral patterns. In short, Ammu's evolutionary development, her adaptation and struggle for survival can aptly be explained in the light of Darwinian Theory.

\section{CONCLUSION}

Violence is a heinous problem that destroys the peaceful co-existence in society. The history of the world has been spoiled with the incidents of violence and aggression. It has always been an integral part of almost every society. Human beings, in one way or the other, have always been engaged in acts of violence and aggression. Researchers have pinpointed various factors, both cultural and biological, that trigger human beings to act violently and aggressively. Most of the research studies conducted on the subject under study have taken violence as a masculine issue. This research, however, adopted a different approach and aimed to explore the acts of violence by the female characters especially Ammu. By doing so, it has attempted to alter the age-old myth that violence is associated merely with the masculinity and that female members of society are not capable of committing violence and crimes. Hence, it has brought into lime light an often- ignored and unacknowledged fact that women also participate and engage in acts of violence and that the study of violence should not be limited to just the male members of society.

\section{REFERENCES}

[1] Al-Quaderi, Go. G. and Saiful , M. "Complicity and Resistance: Women in Arundhati Roy's The God of Small Things. "JPCS, vol.2, no. 4, 2011. PP. 30 - 37.

[2] Africa, Adelena Standpoint: "Murderous Women"? Rethinking Gender AND Theories of Violence. University of Cape Straus, M.A.Conceptualization and measurement of battering: implications for public policy.In M.Steinman (Ed.), Woman Battering: policy responses. Cincinnati, $\mathrm{OH}$ : Anderson Town. 1991.

[3] Artz S. "To die for violent adolescent girls' search for male attention." In Development and Treatment of Girlhood Aggression(eds Peplar D, Madsen K, Webster C, Levene K, editors.), Hillsdale, NJ: Lawrence Erlbaum , 2005.

[4] Bandura, A. "Aggression: A Social Learning Analysis. Toward an experiment ecology of human development." American Psychologist, vol. 32, 1973, pp. 523-621.

[5] Chanda,T. "Sexual/textual strategies in The God of Small Things". Studies, vol.22.2006, pp. 164-167.

[6] Carroll, J. Literary Darwinism: Evolution, Human Nature, and Literature. Routledge, 1992.

[7] David, D. What is Literary Darwinism? An Int. February 27, 2009.

https://neuronarrative.wordpress.com. Accessed 27 Sep. 2017.

[8] Deshapande, S. The Dark Holds No Terror. Penguin Books, India, 1980.

[9] Jain, J. Gender and Narrative Strategy.Between Spaces of Silence: Women Creative Writers .Ed. Kamini Dinesh. New Dehli: Sterling, 1994.

[10] Jonathan, G. and David, S, W. The Literary Animal: Evolution and Nature of Narrative. Northwestern. University Press, 2005.

[11] Kamala, D. The Old Playhouse and Other Poems. Orient Longman, Hyderabad, India, 1973.

[12] Kohn, A. "Are Humans Innately Aggressive"? Psychology Today, June 1998.

[13] Lorenz, Konrad. On Agression.New York: Harcourt, Brace and World, Inc., 1996.

[14] Maxwell, Marilyn. Male Rage Female Fury: Gender 

and Violence in Contemporary American Fiction. Larham: United States of America Press, 2000.

[15] McLeod, S. A. Id, Ego and Superego. 2016. www.simplypsychology.org/psyche.html. Accessed 27 Sep. 2017.

[16] Prakash, S. and Sujata. "Ammu's Frantic Quest for Identity in The God of Small Things." International journal of English Language, Literatura and Translation Studies, vol.3.1.2016, pp. 21 - 35.

[17] Prasad, Amarnath. Feminism and Gender Discrimination in The God of Small Things. Critical Responses to Feminism. New Delhi: Sarup and Sons, 2006.

[18] Roy, A. Men, Women and Aggression.Basic Books, 2004.

[19] Roy, A. The God of Small Things: A Critical Appraisal.Sarup \& Sons. New Dehli, 2004.

[20] Roy, A. The God of Small Things. New Dehli: Atlantic, 2005. 